\title{
Zebrafish (Danio rerio) as a model for investigating the safety of GM feed ingredients (soya and maize); performance, stress response and uptake of dietary DNA sequences
}

\author{
Nini H. Sissener ${ }^{1}$, Lene E. Johannessen ${ }^{2}$, Ernst M. Hevrøy ${ }^{1}$, Christer R. Wiik-Nielsen ${ }^{2}$, Knut G. Berdal ${ }^{2}$, \\ Andreas Nordgreen ${ }^{1}$ and Gro-Ingunn Hemre ${ }^{1}$ \\ ${ }^{1}$ National Institute of Seafood and Nutrition Research (NIFES), Postboks 2029 Nordnes, 5817 Bergen, Norway \\ ${ }^{2}$ Section of GMO and Food Microbiology, Department of Feed and Food Safety, National Veterinary Institute, Oslo, Norway
}

(Received 23 March 2009 - Revised 11 June 2009 - Accepted 26 June 2009 - First published online 26 August 2009)

A 20-d zebrafish (Danio rerio) feeding trial, in which a near doubling of fish weight was achieved, was conducted with GM feed ingredients to evaluate feed intake, growth, stress response and uptake of dietary DNA. A partial aim of the study was to assess zebrafish as a model organism in GM safety assessments. Roundup Ready ${ }^{\circledR}$ soya $\left(\right.$ RRS $\left.^{\circledR}\right)$, YieldGard ${ }^{\circledR}$ Bt maize (MON810) and their non-modified, maternal, near-isogenic lines were used in a $2 \times 2$ factorial design. Soya variety and maize variety were the main factors, both with two levels; non-GM and GM. Compared with fish fed non-GM maize, those fed GM maize exhibited significantly better growth, had lower mRNA transcription levels of superoxide dismutase (SOD)-1 and a tendency (non-significant) towards lower transcription of heat shock protein 70 in liver. Sex of the fish and soya variety had significant interaction effects on total RNA yield from the whole liver and transcription of SOD-1, suggesting that some diet component affecting males and females differently was present in different levels in the GM and the non-GM soya used in the present study. Dietary DNA sequences were detected in all of the organs analysed, but not all of the samples. Soya and maize rubisco (non-transgenic, multicopy genes) were most frequently detected, while MON810 transgenic DNA fragments were detected in some samples and RRS ${ }^{\circledR}$ fragments were not detected In conclusion, zebrafish shows promise as a model for this application.

Zebrafish: GM feed: Roundup $\operatorname{Ready}^{\circledR}$ soya: Bt maize

The zebrafish (Danio rerio) is a commonly used model organism in developmental, molecular and toxicological studies $^{(1-4)}$. This is not the case for nutrition studies; not even the basic nutritional requirements of zebrafish are published $^{(5)}$. However, by using zebrafish as a model organism, duration and cost of trials can be greatly reduced. When working with GM feed ingredients, it is a challenge to obtain a proper control, such as the near-isogenic maternal line of the GM event ${ }^{(6)}$. Thus, it is advantageous that only small amounts are required to conduct a feeding trial. Furthermore, the fact that the zebrafish is omnivorous ${ }^{(7)}$ means that more plant (GM) ingredients can be included in the diets than for carnivorous fish species such as Atlantic salmon (Salmo salar). Out of nineteen approved GM plants for use in animal feeds in Norway, only two, glyphosate-tolerant Roundup Ready ${ }^{\circledR}$ soya (RRS ${ }^{\circledR}$, modification event GTS 40-3-2) and Bt toxinproducing YieldGard ${ }^{\circledR}$ maize (modification event MON810), have been subjected to fish-feeding trials. Thus, it makes sense to develop a model to reduce the costs of testing. Despite difficulty of procuring non-GM varieties of feed ingredients such as soyabean, the Norwegian aquaculture feed industry has so far avoided using GM ingredients ${ }^{(8)}$.
Fish performance and health are issues of economical and animal welfare concern, and might be influenced by the newly expressed protein and/or unintended effects from the GM event. In a previous feeding trial, Atlantic salmon fed MON810 maize exhibited lowered feed intake and growth compared with fish fed the non-GM maternal line ${ }^{(9)}$. Red blood cell count, hepatosomatic index and distal intestine index were significantly higher in the GM group ${ }^{(9)}$. Furthermore, the fish fed GM maize had increased maltase activity in mid and distal intestine and increased Na-dependent D-glucose uptake in brush border membrane vesicles isolated from pyloric caeca ${ }^{(9)}$. Assessment of stress-related proteins in the same trial revealed that superoxide dismutase (SOD) activity in the liver and distal intestine was significantly higher in fish fed GM maize ${ }^{(10)}$. This group also exhibited decreased CAT (catalase) activity and a tendency towards increased heat shock protein (HSP) 70 levels in liver ${ }^{(10)}$. The authors interpreted this as a possible mild stress response in the GM-fed group. As the normal range of these parameters is not known, it is hard to conclude on the long-term biological significance of these findings. In another study in which two MON810 hybrids were fed to Atlantic salmon from first

Abbreviations: HSP, heat shock protein; PFU, PCR-forming units; RRS, Roundup Ready soya; SOD, superoxide dismutase.

* Corresponding author: Nini H. Sissener, fax + 47559052 99, email nsi@nifes.no 
feeding onwards, no differences in growth or organ indices were detected $^{(11)}$.

Fish-feeding studies using GM soya have produced less differences between diet groups, and with no effect on growth $^{(11-15)}$. Significant effects have been seen in these studies on plasma TAG levels and organ indices (spleen and intestine), but the results have been inconsistent or even contradictory between studies ${ }^{(13,14,16)}$, thus can most likely be explained by other factors than the genetic modification per se. Differences in intestinal glucose uptake have been reported, but the control soyabean used was a commercial variety and heat treatments used differed between the non$\mathrm{GM}$ and the GM soya ${ }^{(17)}$. Intestinal cell proliferation was higher in the non-GM-fed fish in a study on salmon parr, also conducted with a commercial soyabean line as control ${ }^{(18)}$.

Transgenic DNA present in food/feed has been a topic of research interest, despite the fact that it does not seem to present safety issues other than conventional dietary DNA ${ }^{(19,20)}$. This includes studies investigating the fate of foreign DNA ingested by fish ${ }^{(21-25)}$. In a study where Atlantic salmon was force-fed high concentrations of DNA fragments, the uptake was observed in liver, kidney and blood, with the highest concentrations in liver and kidney ${ }^{(22)}$. Intravenously injected DNA fragments were detected in muscle, liver, kidney and blood in another study ${ }^{(23)}$. By means of in situ hybridisation, transgenic DNA was identified in intestinal cells of fish fed GM soya, although only in a few of the examined samples ${ }^{(25)}$. Chainark et al. ${ }^{(24)}$ found DNA fragments of the transgenic promoter from $\mathrm{RRS}^{\circledR}$ in the leukocytes, head kidney and muscle of rainbow trout (Oncorhynchus mykiss) fed a GM soya diet.

In the present study, RRS $^{\circledR}$ and MON810, as well as their non-modified lines were tested separately and in combination as feed ingredients in a $2 \times 2$ factorial design. The aims were to compare growth, performance and liver transcription of mRNA coding for different proteins involved in cellular and oxidative stress between fish fed the non-GM and GM varieties. Secondly, we aimed to detect transgenic DNA fragments and rubisco, a chloroplast gene present in plants in high copy numbers, in different tissues of the fish.

\section{Materials and methods}

\section{Diets and experimental design}

The GM varieties Bt maize, event MON810, and RRS ${ }^{\circledR}$, event GTS 40-3-2, and the non-modified lines from which the GM varieties were originally derived, maize cultivar $\mathrm{Hi}-\mathrm{II}$ and soya cultivar A5403 (the maternal, near-isogenic lines), were grown under identical conditions (all kindly supplied by the Monsanto Company, St Louis, MO, USA). The non-GM varieties were grown side by side with the GM varieties, in order to constitute the best possible control for safety assessment of the GM plants ${ }^{(26,27)}$. Analyses of proximate composition and pesticide residues in these are listed in Table 1; there were minor differences in the analysed nutrients and

Table 1. Proximate composition and pesticide residue levels of the raw materials used in the diets

\begin{tabular}{|c|c|c|c|c|}
\hline & Non-GM maize & GM maize & Non-GM soya & GM soya \\
\hline \multicolumn{5}{|l|}{ Composition $(\mathrm{g} / 100 \mathrm{~g})$} \\
\hline DM & $91 \cdot 0$ & $91 \cdot 0$ & $91 \cdot 1$ & 92.9 \\
\hline Lipid & $4 \cdot 2$ & 4.4 & $20 \cdot 5$ & $18 \cdot 2$ \\
\hline Protein & $9 \cdot 5$ & $9 \cdot 1$ & $35 \cdot 1$ & $38 \cdot 2$ \\
\hline Starch & 62.5 & 61.9 & NA & NA \\
\hline Ash & 1.4 & $1 \cdot 3$ & 4.6 & $5 \cdot 0$ \\
\hline Residue* & $13 \cdot 4$ & $14 \cdot 3$ & $39 \cdot 8$ & 38.6 \\
\hline \multicolumn{5}{|l|}{ Pesticides $(\mu \mathrm{g} / \mathrm{kg})$} \\
\hline Aldrin & $<0.6$ & $<0.6$ & $<0.6$ & $<0.6$ \\
\hline$\alpha$-Endosulfan & $<0.5$ & $<0.5$ & $<0.3$ & $<0.3$ \\
\hline Endosulfan sulphate† & NA & NA & $<0.5$ & $<0.5$ \\
\hline$\beta$-Endosulfan & NA & NA & $<0.3$ & $<0.3$ \\
\hline cis-Chlordane & $<0.5$ & $<0.5$ & $<0.5$ & $<0.5$ \\
\hline cis-Nonachlor & $<0.7$ & $<0.7$ & $<1.5$ & $<1.5$ \\
\hline Dieldrin & $<0.3$ & $<0.3$ & NA & NA \\
\hline Endrin & $<1$ & $<1$ & NA & NA \\
\hline Heptachlor & $<2.5$ & $<2.5$ & $<2.5$ & $<2.5$ \\
\hline Heptachlor-A & $<0.5$ & $<0.5$ & $<0.5$ & $<0.5$ \\
\hline Oxychlordane & $<1 \cdot 3$ & $<1 \cdot 3$ & $<1.3$ & $<1 \cdot 3$ \\
\hline Toxaphene 26 & $<2.5$ & $<2.5$ & $<1.0$ & $<1.0$ \\
\hline Toxaphene 32 & $<1.5$ & $<1.5$ & $<0.7$ & $<0.7$ \\
\hline Toxaphene 50 & $<2.5$ & $<2.5$ & $<2.5$ & $<2.5$ \\
\hline Toxaphene 62 & $<1.5$ & $<1.5$ & $<1.5$ & $<1.5$ \\
\hline trans-Chlordane & $<0.7$ & $<0.7$ & $<0.7$ & $<0.7$ \\
\hline trans-Nonachlor & $<0.5$ & $<0.5$ & $<0.5$ & $<0.5$ \\
\hline$\alpha$-Hexachlorocyclohexane & NA & NA & $<0.6$ & $<0.6$ \\
\hline Hexachlorobenzene & NA & NA & 0.13 & 0.88 \\
\hline$\gamma$-Hexachlorocyclohexane & NA & NA & $<2 \cdot 0$ & $<2 \cdot 0$ \\
\hline
\end{tabular}

NA, not available.

${ }^{*}$ Residue for maize was calculated as DM - (protein + lipid + starch + ash), residue for the soyabean meal also includes the starch fraction.

†Differences in limit of detection for some of the pesticides between analysis on the maize and soya and some differences in what pesticides were analysed are due to changes in the method between the time when the maize and the soya samples were processed. 
none in the analysed pesticides. Additionally, we have previously analysed the soya batch used in this trial for a range of anti-nutritional factors ${ }^{(14)}$, while maize is known to have a low content of these ${ }^{(28)}$. Four experimental diets were designed with the same composition, the only difference between them being whether the soya and maize included were GM or not. In the first diet, maize and soya were both included as non-modified varieties (the non-GM diet); in the second, only the maize was GM (mGM); in the third, only the soya was GM (sGM); while in the fourth diet, both soya and maize were GM (smGM). Thus, these four diets constituted a $2 \times 2$ factorial design with soya and maize variety as the two factors, each with two levels, non-GM and GM. Each diet was fed to three replicate, randomly allocated, fish tanks. The diets contained $20 \%$ maize, which was the major source of starch, and $25 \%$ full fat soyabean meal supplying protein and lipid. Additional protein came from cod fillet and squid (squid was also added as a feed attractant), and additional lipid was provided from cod liver oil. Vitamin and mineral mixes were added according to $\mathrm{NRC}^{(57)}$. The formulation of the feeds is given in Table 2. In addition to the four experimental diets, a commercial diet (Teklad adult zebrafish diet, Harlan Teklad, Madison, WI, USA) was fed to triplicate tanks. This diet had other ingredients (fishmeal, high gluten wheat starch, blood meal, maize gluten, fish oil, wheat, liquid fish soluble as well as various additives) and a different proximate composition. The purpose of including this diet was not related to GM plant evaluation, but was simply to evaluate the feed production process and ensure that an acceptable growth rate was achieved with the experimental diets. It was not checked whether or not this diet contained GM material, as this was considered irrelevant. This diet was also crushed and sieved (see below) to obtain the same size fraction as the experimental diets.

Heat-coagulated experimental diets were made. All ingredients were blended to a visually homogenous mixture in a standard food processor, and the resulting feed dough was made into $1.5 \mathrm{~cm}$ thick strings. These were heat treated for $12 \mathrm{~min}$ at $83^{\circ} \mathrm{C}$ to denature the protein, with $100 \%$ humidity to avoid the formation of a crust, in a convection oven (SCC 202, Rational AG, Landsberg am Lech, Germany). The feed was subsequently dried in the same oven for $24 \mathrm{~h}$ with a maximum temperature of $45^{\circ} \mathrm{C}$ and $0 \%$ humidity. All four feeds

Table 2. Formulation of the four experimental diets; the composition was the same for all diets, the only difference was whether the maize and soya were GM or not

\begin{tabular}{|c|c|}
\hline Ingredient & DM in diet (\%) \\
\hline Maize* & 20 \\
\hline Cod fillet† & $39 \cdot 0$ \\
\hline Cod liver oilł & $7 \cdot 6$ \\
\hline Squid† & 4.4 \\
\hline Full fat soyabean meal* & $25 \cdot 0$ \\
\hline Vitamin mix§ & $1 \cdot 0$ \\
\hline Mineral mix§ & $3 \cdot 0$ \\
\hline
\end{tabular}

* Monsanto Company (St Louis, MO, USA).

† Lerøy, Bergen, Norway.

$\ddagger$ Peter Möller, Lysaker, Norway.

$\S$ Harlan Teklad, Madison, WI, USA. were made at the same time to prevent any differences in time, temperature etc in the processing of the diets. The feeds were then ground (Mg 1-314, Frewitt, Granges-Paccot, Switzerland) and sieved (As200 basic, Retsch, Düsseldorf, Germany) to obtain the desired particle size fraction. Particles between 400 and $560 \mu \mathrm{m}$ were used. The feed was kept refrigerated at $4^{\circ} \mathrm{C}$ until use.

Dietary moisture was analysed by drying at $103^{\circ} \mathrm{C}$ for $24 \mathrm{~h}$, ash by weight after burning at $540^{\circ} \mathrm{C}$ and lipid after extraction with ethyl acetate ${ }^{(29)}$. Nitrogen was measured with a nitrogen determinator (LECO, FP-428, Leco Corporation, St Joseph MI, USA) according to Association of Official Agricultural Chemists official methods of analysis ${ }^{(30)}$ and protein calculated as $N \times 6 \cdot 25$. Starch was measured after enzymatic degradation as described by Hemre et al. ${ }^{(31)}$. Vitamin $\mathrm{B}_{6}$ was determined by $\mathrm{HPLC}^{(32)}$. Multielement determination in the feed was done by inductively coupled plasma $\mathrm{MS}^{(33)}$. Pesticides were determined by GCMS on a Trace GC 2000 series and Trace DSQ single quadrupole (Thermo Fisher Scientific, Waltham, MA, USA $)^{(34,35)}$. Both the maize and soya used as diet ingredients and the four experimental diets were tested for the presence of the transgenic proteins Cry1Ab and EPSPS expressed in MON810 and RRS ${ }^{\circledR}$, respectively, using lateral flow strip assays (QuickStrix ${ }^{\text {TM }}$ Kit for Cry1Ab bulk grain/for Roundup Ready ${ }^{\circledR}$ bulk soyabeans, EnviroLogix ${ }^{\mathrm{TM}}$, Portland, ME, USA). The test for each ingredient/diet was run in triplicate with $0 \cdot 25 \mathrm{~g}$ sample material each time.

\section{Fish husbandry and sampling}

Tubingen $\times$ AB wild-type zebrafish of $60 \mathrm{~d}$ old were supplied by the SARS centre (Bergen, Norway). The experiment was conducted in an AHAB multiple rack zebrafish system (Aquatic habitats, Aquatic Eco-Systems, Apopka, FL, USA) with reverse osmosis followed by automatic salt dosing of intake water, UV, mechanical and carbon filtration of the water. The fish were distributed in seven 101 tanks where they were allowed to acclimatise for $6 \mathrm{~d}$, while being fed a commercial zebrafish diet (Teklad adult zebrafish diet that was also used as a reference diet in the experiment). At the start of the experiment, the fish (mean weight $149 \mathrm{mg}$, SD 22) were distributed in the fifteen experimental tanks (31), with seventeen fish each. All fish were examined during the distribution, and fish that were especially big or small, or had spinal or jaw deformities, were not used in the experiment to achieve a material that was as homogenous as possible. Temperature, $\mathrm{pH}$, salinity and conductivity were monitored on a daily basis. The mean temperature was $27 \cdot 2^{\circ} \mathrm{C}$ (SD 0.9), the $\mathrm{pH} 7 \cdot 12$ (SD $0 \cdot 29$ ), salinity 0.3 (SD 0) and conductivity 601uS (SD 99). Ammonia $\left(\mathrm{NH}_{3} / \mathrm{NH}_{4}\right)$, nitrate $\left(\mathrm{NO}_{3}^{-}\right)$, nitrite $\left(\mathrm{NO}_{2}^{-}\right)$and oxygen were measured weekly. The fish were hand fed to satiation three times a day, and feed consumption per tank was recorded daily.

The experiment was terminated after $20 \mathrm{~d}$ of feeding, when the fish had near doubled their weight and would presumably have been affected by the diet ingredients. As zebrafish reach sexual maturity within 3-4 months after fertilisation, this represents a not insignificant part of the life cycle. A time lag in the last feeding ensured that each tank was sampled at the same time interval after their last meal to avoid differences in nutritional status. The fish were killed by a sharp 
object to the head, before weight and length were measured. On the fish used for mRNA analysis, the head and tail were cut off and the remainder of the fish was fixed in a $10 \times$ volume of RNAlater ${ }^{\circledR}$ (Ambion, Austin, TX, USA) and stored in the fridge at $4^{\circ} \mathrm{C}$ until liver was dissected under a dissecting microscope. The sex of the fish was determined upon dissection. For tracing of dietary DNA sequences, fish were flash frozen whole in liquid nitrogen. Tracing and mRNA analysis were only done on fish fed the four experimental diets, not the commercial diet.

The feeding trial was approved by the National Animal Research Authority in Norway, case no. 07/16836.

\section{Transcriptional (mRNA) analysis}

The RNeasy mini kit (Qiagen, Hilden, Germany) was used for RNA extraction according to the manufacturer's instructions. Tissue was homogenised in buffer from the kit on the bead grinder homogenizer Precellys 24 (Bertin Technologies, Montigny-le-Bretonneaux, France) for $3 \times 10 \mathrm{~s}$ at $6000 \mathrm{rpm}$. DNase treatment (DNA free, Ambion) was applied to eliminate any DNA contamination and ethanol precipitation to remove salts. RNA quantity and quality were assessed with Nanodrop ${ }^{\circledR}$ ND-1000 UV-Vis spectrophotometer (NanoDrop Technologies, Wilmington, DE, USA) and the Agilent 2100 Bioanalyzer with the RNA 6000 Nano LabChip ${ }^{\circledR}$ kit (both Agilent Technologies, Pao Alto, CA, USA). Samples with RNA integrity number lower than 6 were discarded. The average RNA integrity number value of the samples used was 8.1 (SD 0.9). Samples were stored at $-80^{\circ} \mathrm{C}$ for further use, and three samples per tank (nine per experimental diet) were used.

Primer sequences were obtained from the literature for the

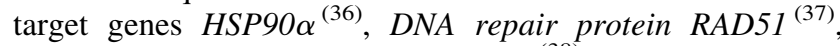
SOD -1 and glutathione peroxidase $-1^{(38)}$ and the potential reference genes $\beta$-actin, elongation factor $1 \alpha$, hypoxanthine guanine phosphoribosyl transferase 1 and ribosomal protein $L 13 \alpha^{(39)}$. For $H S P 70$, forward and reverse primers were designed using Primer Express ${ }^{\circledR} 2.0$ (Applied Biosystems, Foster City, CA, USA). Sequences of all primer pairs (Invitrogen, Life Technologies, Carlsbad, CA, USA) are given in Table 3. Samples were run in a 96-well format, and all samples fit into one cDNA (RT) plate, but separate real-time plates were run for each gene. A twofold serial dilution curve (500-31.25 ng RNA) of a pooled sample was run with six dilutions in triplicate for calculation of PCR efficiency. Non-template and non-amplification controls were also used, in addition to the experimental samples in duplicate (125 $\mathrm{ng}$ RNA). Reverse transcription was performed on a GeneAmp ${ }^{\circledR}$ PCR 9700 machine (Applied Biosystems), using the TaqMan ${ }^{\circledR}$ Reverse Transcriptase kit with oligo(dT) primers (Applied Biosystems) in $50 \mu \mathrm{l}$ reactions. For real-time PCR, $18 \mu \mathrm{l}$ SYBR $^{\circledR}$ Green I Mastermix (Roche Applied Science, Indianapolis, IN, USA) with forward and reverse primers $(0.5 \mu \mathrm{M}$ of each) and $2 \mu \mathrm{l}$ of the cDNA were mixed in 96-well plates by Biomek $^{\circledR} 3000$ Laboratory automation workstation (Beckman Coulter, Fullerton, CA, USA). Thermal cycling was performed on a LightCycler ${ }^{\circledR} 480$ System (Roche Applied Science) according to the following protocol: pre-incubation at $95^{\circ} \mathrm{C} ; 45$ cycles of amplification with 10,20 and $30 \mathrm{~s}$ at 95,20 and $72^{\circ} \mathrm{C}$, respectively; and finally melting curve analysis.

$C_{t}$ values were calculated using the second maximum derivative method in the Lightcycler ${ }^{\circledR}$ software. Twofold dilution curves were used to determine the efficiency with the formula $E=10 \wedge(-1 /$ slope $)$, with the slope of the linear curve of $C_{t}$ values plotted against the $\log$ dilution ${ }^{(40)}$. The geNorm VBA applet ${ }^{(41)}$ and NormFinder ${ }^{(42)}$ were used to investigate reference gene stability. Based on the results, all four of the tested reference genes were included to achieve the most stable normalisation index. The software package GenEx 4.3.5 (MultiD Analyses AB, Gothenburg, Sweden) was used for efficiency correction of the $C t$ values for all genes, normalisation to reference genes, averaging of the RT repeats, calculation of quantities relative to the average and $\log (2)$ transformation of the numbers.

\section{Detection of dietary DNA fragments}

These analyses were conducted at the National Veterinary Institute (Oslo, Norway), which is an accredited laboratory for GMO detection. Frozen zebrafish were thawed on ice before isolation of organs in the following order: intestinal organs; liver; brain; muscle. Intestinal organs included the stomach and the whole intestine. One fish from each tank from the four experimental diets was investigated. The equipment was sterilised using $70 \% \mathrm{EtOH}$ and flaming before isolation of each organ. A fresh sheet of single-use bench paper was used for each fish. The organs were transferred to sterile test-tubes, and DNA isolated using the DNeasy Blood and Tissue kit (Qiagen GmbH, Germany) according to the manufacturer's procedures and eluted in $100 \mu$ l elution buffer. DNA was isolated from $200 \mathrm{mg}$ of the four experimental

Table 3. Sequences and accession numbers of the primer pairs used

\begin{tabular}{llll}
\hline Gene & Forward primer & Reverse primer & Accession no. \\
\hline EF1 $\alpha$ & CTGGAGGCCAGCTCAAACAT & ATCAAGAAGAGTAGTACCGCTAGCATTAC & ENSDART00000023156 \\
$H P R T$ & ATCAGCGAAACAGGAAAGGAG & CTGCGGTGAGCTGCACTACT & NM_212986 \\
$\beta$-actin & CGAGCTGTCTTCCCATCCA & TCACCAACGTAGCTGTCTTCTG & ENSDART00000055194 \\
Rpl13 $\alpha$ & TCTGGAGGACTGTAAGAGGTATGC & AGACGCACAATCTTGAGAGCAG & NM_212784 \\
HSP70 & CATCGACGCCAACGGG & CCAGGGAGTTTTAGCAGAAATCTT & AF210640 \\
HSP90 $\alpha$ & AGCTGGCGGATCGTTCACTGTC & AAAACTCGCCGTACTCCTCATTGG & AF068773 \\
DNA-rep. prot & CGTCTCGCTGATGAGTTTGG & CCACCTGTGCTACAACCTGGTT & AW184428 \\
SOD1 $(\mathrm{Cu}-\mathrm{Zn})$ & CGCATGTTCCAGACATCTA & GAGCGGAAGATTGAGGATTG & Y12236 \\
GPx-1 & AGATGTCATTCCTGCACACG & AAGGAGAACTTCCTCAGCC & AW232474 \\
\hline
\end{tabular}

EF1 $\alpha$, elongation factor $1 \alpha$; HPRT, hypoxanthine guanine phosphoribosyl transferase; Rpl13 $\alpha$, ribosomal protein L13 $\alpha$; HSP, heat shock protein; DNA-rep. prot, DNA repair protein RAD51; SOD, superoxide dismutase; GPx, glutathione peroxidase. 
diets using a slightly modified version of the CTAB method ${ }^{(43)}$ and resolved in $120 \mu \mathrm{l}$ TE buffer. The DNA concentration of each sample $(\mu \mathrm{g} / \mu \mathrm{l})$ was measured using a NanoDrop ND-1000 Spectrophotometer (NanoDrop Technologies).

Quantitative PCR was used to detect the GM insert in RRS $^{\circledR}$ soya and MON810 maize, and to detect the chloroplast multicopy rubisco gene from soya (sRubisco) and maize (mRubisco). Event specific primers and probes were used for $\operatorname{RRS}^{\circledR(44)}$ and MON810 ${ }^{(45)}$, while primer and probe sequences were constructed for sRubisco (accession number: Z95552) and mRubisco (accession number: Z11973) using Primer3 (http://primer3.sourceforge.net/). Primer and probe sequences are given in Table 4. Probes were labelled as 5'Fam-3'Tamra. The PCR volume was $25 \mu \mathrm{l}$, containing $5 \mu \mathrm{l}$ of DNA, $0 \cdot 3 \mu \mathrm{M}$ of each primer and $0 \cdot 15 \mu \mathrm{M}$ of probe in $1 \times$ TaqMan Universal PCR Master mix (\#4304437, Applied Biosystems). Amplification reactions were performed using Stratagene Mx3005P real-time cycler (Stratagene, La Jolla, CA, USA), with the amplification programme: $2 \mathrm{~min}$ at $50^{\circ} \mathrm{C} ; 10 \mathrm{~min}$ at $95^{\circ} \mathrm{C} ; 50$ cycles of $15 \mathrm{~s}$ at $95^{\circ} \mathrm{C} ; 60 \mathrm{~s}$ at $60^{\circ} \mathrm{C}$ (MON810, sRubisco and mRubisco) or $61^{\circ} \mathrm{C}\left(\mathrm{RRS}^{\circledR}\right)$. Fluorescence measurements were analysed using the MxPro 3005 QPCR software (Stratagene). Two parallels were used when analysing for rubisco, and the number of PCR-forming units $(\mathrm{PFU}) / \mu \mathrm{l}$ in the samples was calculated using a standard in the range of $1 \times 10^{5}-1 \times 10^{1} \mathrm{PFU} / \mu \mathrm{l}$. Limit of quantification for sRubisco and mRubisco was 50PFU, while the limit of detection was 5 PFU. When analysing for RRS ${ }^{\circledR}$ and MON810, PFU/ $\mu$ l were calculated according to the most probable number method (SIMQUANT) ${ }^{(46-48)}$, using eight parallels. When analysing for $\mathrm{RRS}^{\circledR}$ and MON810 in the diets, $\mathrm{PFU} / \mu \mathrm{l}$ were calculated using a standard curve in the range of $5 \cdot 12 \times 10^{2}-8 \mathrm{PFU} / \mu \mathrm{l}$. The limit of detection and limit of quantification for quantification of RRS ${ }^{\circledR}$ and MON810 in the diets were 40 and $5 \mathrm{PFU}$, respectively. PFU/ $\mu$ l detected in the samples were used to calculate PFU/ $\mu$ g of DNA.

\section{Statistical analysis}

Statistical analyses were performed in Statistica ${ }^{\text {TM }} 8.0$ (Statsoft Inc., Tulsa, OK, USA). For the parameters obtained on a tank basis (SGR, FI and FCR), classical ANOVA was used. However, for parameters measured on individual fish, mixed-effects ANOVA was used, including the fish tanks as a random factor in the model. This gave a nested (hierarchical) model as the different tanks were nested within the diet treatments, and thus individual fish from the same tank were only pseudoreplicates. Nested ANOVA maintains both the between-tank and within-tank variabilities in the analysis, the latter is lost when the individual measurements are pooled and tank means calculated ${ }^{(49,50)}$. The nested test will often be more powerful in resolving treatment differences, as statistical power in this design can be increased either by increasing the number of tanks or by increasing the number of individual measurements made from each tank, albeit to different extents ${ }^{(49,51)}$.

The commercial reference diet was compared with all the experimental diets (pooled), as our only interest here was simply to compare a commercial diet to the 'home-made' diets. In the experimental diets, the soya and maize ingredients were used in a $2 \times 2$ factorial design, with two factors (maize variety and soya variety) and two levels within each factor (non-GM and GM). All of the possible combinations (each level of each factor combined with every other) were used in each of our four experimental diets. Thus, although each experimental diet only was fed to three replicate tanks, each ingredient being studied (e.g. GM soya) was fed to six replicate tanks. In the comparisons of fish fed the experimental diets, the variables used for testing were maize and soya varieties, the four individual diet groups were not used as factors in the statistical testing. Sex was included as a factor in the model if found to exert a significant effect on that particular parameter/gene. The mRNA transcription data were $\log (2)$ transformed to obtain normality, assessed by the Kolmogorov-Smirnov test. Correlation between the RNA integrity number values and normalised expression levels in the samples was tested for each target gene. Three of the genes showed a positive correlation (significant or close to significant); meaning that better quality RNA resulted in apparent higher expression (Table 5), as reported by others $^{(52-54)}$. To correct for this, the RNA integrity number value was included as a covariate in the statistical model for these genes. The significance threshold was set at $P<0 \cdot 05$, but all $P$ values $<0 \cdot 10$ are given in the tables.

\section{Calculations}

$$
\begin{aligned}
& \text { Condition factor }(\mathrm{K})=\left(\text { weight } / \text { length }^{3}\right) \times 100 \\
& \text { Specific growth rate }=\left(\ln W_{\mathrm{f}}-\ln W_{\mathrm{i}} \times 100\right) / t\left(W_{\mathrm{f}},\right. \text { final } \\
& \text { weight; } \mathrm{W}_{\mathrm{i}} \text {, initial; } t \text {, time in } \mathrm{d} \text { ) }
\end{aligned}
$$

Feed conversion ratio $=$ feed intake $/$ weight gain.

\section{Results}

When comparing the macro- and micronutrient composition of the four experimental diets (the non-GM, mGM, sGM and smGM diets; Table 6), these were compositionally very similar. The transgenic protein Cry1 Ab was detected in the

Table 4. Primer and probe sequences for detection of dietary DNA fragments from feeds and zebrafish tissues

\begin{tabular}{llll}
\hline & Forward primer & Reverse primer & Probe \\
\hline RRS $^{\circledR}$ & TAGCATCTACATATAGCTTC & GACCAGGCCATTCGCCTCA & ACAAAACTATTTGGGATCGGAGAAGA \\
MON810 & TCGAAGGACGAAGGACTCTAACGT & GCCACCTTCCTTTCCACTCTCTT & AACATCCTTTGCCATTGCCCAGC \\
sRubisco & GGGCTTACCAGTCTTGATCG & TGATTTCTTCCCCAGCAAC & GGGCGATGCTACGGCCTTGA \\
mRubisco & GCCTGTGTACAAGCTCGTAACG & CACTCCATTTGCAAGCTGCTT & AGGGCGCGATCTTGCTCGTGAA \\
\hline
\end{tabular}

RRS, Roundup Ready soya; sRubisco, rubisco gene from soya; mRubisco, rubisco gene from maize. 
Table 5. Correlation between RNA integrity number value of the RNA samples and normalised relative $\mathrm{mRNA}$ transcription

\begin{tabular}{lrl}
\hline Gene & $R^{2}$ & $P$ value \\
\hline HSP70 & -0.05 & NS \\
HSP90 & 0.04 & NS \\
SOD-1 $(\mathrm{Cu}-Z n)$ & 0.48 & 0.005 \\
DNA-rep. prot. & 0.34 & NS, $P=0.054$ \\
GPX-1 & 0.44 & 0.011
\end{tabular}

HSP, heat shock protein; SOD, superoxide dismutase DNA-rep. prot, DNA repair protein RAD51; GPx, glutathione peroxidase.

GM maize and EPSPS in the GM soya (three out of three samples positive for both), but all diet samples were negative, presumably due to denaturation of protein during heat treatment of the diets ${ }^{(55)}$. The reference diet had higher protein and energy levels and a lower residue content (Table 6); this was unavoidable as we wanted to include high levels of the GM plant materials. Most minerals were present in higher levels in the reference diet, and there was also a difference in vitamin $B_{6}$ (the only vitamin measured). All the feeds were accepted by the fish, although feed intake was significantly higher $(P=0.0005)$ on the reference diet compared with the four experimental diets (Table 7). The reference diet resulted in better growth compared with the experimental diets, observed by a higher growth rate and final weight $(P=0 \cdot 005)$. The experiment passed without unexpected events, mortality was low, and there were no differences between the diet groups in this regard. The remainder of the results is based on comparisons between the four experimental diets only, as the reference diet is of no relevance to the GM ingredients investigated in this trial.

There was a significant $(P=0 \cdot 02)$ reduction of feed intake in the groups fed GM soya compared with non-GM (Table 7). However, there were no corresponding effects observed on growth or feed conversion ratio. A significantly higher $(P=0.045)$ weight was obtained with GM maize compared with non-GM maize. There was also a tendency towards a difference in length between these groups $(P=0.08)$, but the condition factor was similar. Highly significant sex differences in final weight, condition factor and total RNA yield from the whole liver (presumably correlating to the size of the liver) were observed (all with $P<0.0001$ ); thus, sex was included in the statistical model for these parameters. Furthermore, there was a significant interaction effect of soya variety (GM or non-GM) and sex on whole-liver RNA yield $(P=0.003)$, and also a nearly significant effect $(P=0.06)$ of GM soya by itself on this parameter (Fig. 1).

Transcription of $S O D-1$ was found to be significantly affected by GM maize $(P=0.03)$ and by sex $(P=0.03$; Table 8; Fig. 2). Transcription of this gene was higher in fish fed non-GM maize compared with GM maize, and higher in female than in male fish. There was also a significant interaction effect between soya variety and sex $(P=0 \cdot 004)$. For HSP70, there was a nearly significant difference between GM and non-GM maize $(P=0 \cdot 08)$. The fold difference was

Table 6. Analyses of the four experimental diets and the commercial reference

\begin{tabular}{|c|c|c|c|c|c|}
\hline & Non-GM & mGM & sGM & smGM & Commercial $^{*}$ \\
\hline \multicolumn{6}{|l|}{ Proximate composition } \\
\hline $\mathrm{DM}(\mathrm{g} / 100 \mathrm{~g})$ & $91 \cdot 7$ & 93.5 & $90 \cdot 0$ & $93 \cdot 3$ & $93 \cdot 3$ \\
\hline Ash $(\mathrm{g} / 100 \mathrm{~g})$ & $7 \cdot 2$ & $7 \cdot 2$ & $7 \cdot 0$ & $7 \cdot 1$ & $7 \cdot 7$ \\
\hline Protein $(\mathrm{g} / 100 \mathrm{~g})$ & 42.9 & $43 \cdot 4$ & $41 \cdot 6$ & $43 \cdot 3$ & $51 \cdot 7$ \\
\hline Lipid (g/100 g) & $13 \cdot 5$ & $13 \cdot 3$ & $13 \cdot 2$ & $13 \cdot 2$ & $14 \cdot 7$ \\
\hline Starch $(\mathrm{g} / 100 \mathrm{~g})$ & $13 \cdot 3$ & $13 \cdot 7$ & $13 \cdot 0$ & $13 \cdot 3$ & $13 \cdot 6$ \\
\hline Residue $(\mathrm{g} / 100 \mathrm{~g}) \dagger$ & $14 \cdot 8$ & $15 \cdot 9$ & $15 \cdot 2$ & $16 \cdot 4$ & $5 \cdot 6$ \\
\hline Energy $(\mathrm{kJ} / \mathrm{g}) \ddagger$ & $17 \cdot 7$ & $17 \cdot 9$ & $17 \cdot 3$ & $17 \cdot 7$ & $20 \cdot 3$ \\
\hline \multicolumn{6}{|l|}{ Vitamins (mg/kg) } \\
\hline Vitamin $\mathrm{B}_{6}$ & 22 & 23 & 20 & 17 & 74 \\
\hline \multicolumn{6}{|l|}{ Elements (mg/kg) } \\
\hline V & 0.10 & 0.12 & 0.12 & 0.11 & $1 \cdot 10$ \\
\hline $\mathrm{Mn}$ & 58 & 63 & 58 & 61 & 91 \\
\hline $\mathrm{Fe}$ & 93 & 110 & 110 & 99 & 620 \\
\hline Co & 0.03 & 0.04 & 0.11 & 0.08 & $1 \cdot 2$ \\
\hline $\mathrm{Cu}$ & $7 \cdot 3$ & $9 \cdot 3$ & $8 \cdot 4$ & $7 \cdot 1$ & 47 \\
\hline $\mathrm{Zn}$ & 49 & 52 & 48 & 51 & 120 \\
\hline As & $1 \cdot 8$ & $2 \cdot 1$ & $2 \cdot 0$ & 7.5 & 3.3 \\
\hline $\mathrm{Se}$ & 0.85 & 1.0 & 0.79 & 0.83 & 2.4 \\
\hline $\mathrm{Sr}$ & $9 \cdot 8$ & $7 \cdot 0$ & $5 \cdot 8$ & $4 \cdot 6$ & 31 \\
\hline Mo & 0.77 & $1 \cdot 1$ & $1 \cdot 6$ & 0.98 & 0.59 \\
\hline $\mathrm{Ag}$ & $<0.01$ & $<0.01$ & $<0.01$ & $<0.01$ & $<0.01$ \\
\hline $\mathrm{Cd}$ & 0.02 & 0.03 & 0.03 & 0.02 & 0.09 \\
\hline Sn & 0.04 & 0.04 & 0.04 & 0.10 & 0.04 \\
\hline $\mathrm{Ba}$ & 4.4 & $5 \cdot 1$ & $3 \cdot 2$ & $3 \cdot 3$ & 2.5 \\
\hline $\mathrm{Hg}$ & 0.13 & 0.20 & 0.19 & 0.19 & 0.04 \\
\hline $\mathrm{Pb}$ & 0.04 & 0.04 & 0.04 & 0.04 & 0.15 \\
\hline
\end{tabular}

The results are presented as the average of two analytical parallels.

${ }^{\star}$ Commercial zebrafish diet (Harland Teklad, MD, USA).

† Residue was calculated as DM - (ash + protein + lipid + starch)

$\ddagger$ Gross energy was calculated according to $\operatorname{Tacon}^{(88)}$ using the energy content of $39.5 \mathrm{~kJ} / \mathrm{g}$ for lipid, $23.6 \mathrm{~kJ} / \mathrm{g}$ for protein and $17.2 \mathrm{~kJ} / \mathrm{g}$ for starch. 
Table 7. Growth and feed performance

(Mean values with their standard errors of each diet group)

\begin{tabular}{|c|c|c|c|c|c|c|c|c|c|c|c|}
\hline & \multicolumn{2}{|c|}{ non-GM } & \multicolumn{2}{|c|}{ mGM } & \multicolumn{2}{|c|}{ sGM } & \multicolumn{2}{|c|}{ smGM } & \multicolumn{2}{|c|}{ Commercial } & \multirow[b]{2}{*}{ ANOVA } \\
\hline & Mean & $\overline{\text { SEM }}$ & Mean & $\overline{\mathrm{SEM}}$ & Mean & SEM & Mean & $\overline{\text { SEM }}$ & Mean & $\overline{\text { SEM }}$ & \\
\hline Weight (mg) & 257 & 8 & 271 & 9 & 253 & 11 & 269 & 8 & 315 & 15 & NSt, $P=0.005^{\star}, P=0.05 \ddagger$ \\
\hline Length (cm) & $2 \cdot 85$ & 0.02 & 2.91 & 0.02 & 2.85 & 0.04 & 2.93 & 0.03 & 2.98 & 0.04 & $\mathrm{NS}^{\star} \dagger \ddagger\left(P=0.06^{\star}, P=0.08 \dagger\right)$ \\
\hline $\mathrm{K}$ & $1 \cdot 11$ & 0.03 & 1.09 & 0.02 & 1.09 & 0.03 & 1.09 & 0.04 & 1.16 & 0.04 & $N S^{*}+\ddagger$ \\
\hline SGR & $2 \cdot 84$ & 0.24 & $3 \cdot 14$ & 0.07 & 2.79 & 0.36 & 3.12 & 0.12 & 3.95 & 0.41 & NSt‡ $\left(P=0.005^{\star}\right)$ \\
\hline $\mathrm{FI}(\mathrm{mg})$ & 186 & 3 & 189 & 6 & 183 & 2 & 174 & 2 & 212 & 9 & NStキ $\left(P=0.0005^{\star}, P=0.02 \dagger\right)$ \\
\hline FCR & $1 \cdot 78$ & $0 \cdot 18$ & 1.56 & 0.04 & 1.82 & 0.27 & 1.45 & 0.08 & 1.30 & 0.14 & $\mathrm{NS}^{*} \dagger \ddagger\left(P=0.08^{*}\right)$ \\
\hline
\end{tabular}

SGR, specific growth rate; $\mathrm{FI}$, feedintake; FCR, feed conversion ratio.

Weight, length and condition factor (K) are measured on individual fish (43-48 per diet), but nested within the respective tanks in the ANOVA to account for pseudoreplication. The growth rate (SGR), FI and FCR are calculated on a tank basis ( $n 3$ per diet). Note that the statistical testing was not performed to compare individual diet groups, but on the factors 'soya variety' and 'maize variety' for the experimental diets. The reference diet was tested against all the experimental diets together.

Initial values: weight 149 (SD 22) $\mathrm{mg}$, length 2.6 (SD 0.2 ) $\mathrm{cm}$ and condition factor 0.83 (SD 0.10 ).

${ }^{*}$ Commercial reference $v$. the four experimental diets.

†Soya variety (GM v. non-GM).

$\ddagger$ Maize variety (GM $v$. non-GM).

large, with a 6.5 times higher mean expression level in the fish fed non-GM maize compared with GM, but due to large variation this difference was not significant. In comparison, the observed fold difference in $S O D-1$ was only $1 \cdot 2$, but this mRNA exhibited much more consistent expression levels with low variability within groups. For the remainder of the genes, no significant differences were observed.

The concentration of DNA isolated from samples for detection of dietary DNA was in the range $68-184 \mathrm{ng} / \mu \mathrm{l}$ for intestinal organs, $47-114 \mathrm{ng} / \mu \mathrm{l}$ for liver, $5-25 \mathrm{ng} / \mu \mathrm{l}$ for brain, $5-16 \mathrm{ng} / \mu \mathrm{l}$ for muscle and $90-190 \mathrm{ng} / \mu \mathrm{l}$ in the feed samples. DNA fragments of $\mathrm{RRS}^{\circledR}$ and MON810 were detected in feed samples from all the experimental diets, although only in amounts just above the detection level in the diets not formulated with that GM ingredient (Table 9). The concentration in the diet samples of DNA fragments from RRS ${ }^{\circledR}$ was approximately seven times higher than the concentration of fragments from MON810. Soya and maize rubisco were present at high levels in all diets. Transgenic DNA from RRS ${ }^{\circledR}$ was not detected in any of the analysed organs (data not shown). MON810 fragments could be detected in some samples of intestinal organs and in one liver sample, all in fish fed GM maize diets (Table 10).

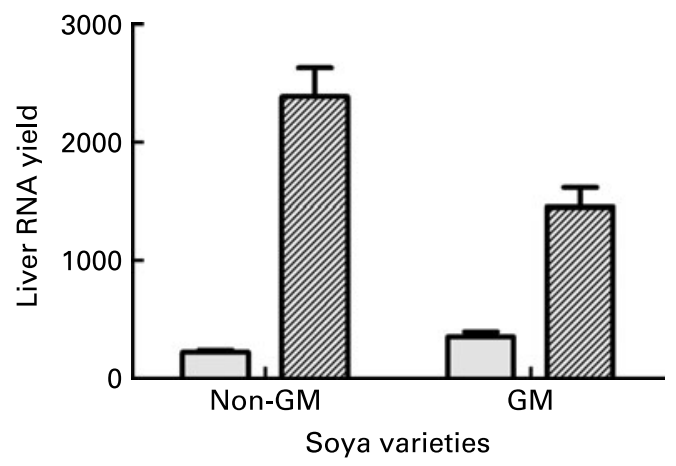

Fig. 1. Total liver RNA yield. RNA yield is given as $n g / \mu l$ when the total RNA is diluted in $50 \mu \mathrm{l}$. The data are given as the means with their standard errors as the error bar ( $\square$, male; $\mathbb{Z}$, female). Soya variety: $P=0.06$; sex: $P>0.0001$; interaction: $P=0.003$.
Soya and maize rubisco (Tables 11 and 12) could be detected in several samples of each of the analysed organs. Rubisco sequences could be detected in the intestinal samples of all individuals, but in other organs the presence was more variable, it could only be detected at low levels and not in all of the fish. The level of rubisco in all organs, except the intestinal organs, was near the detection limit and below limit of quantification. There were no differences in the level of rubisco when comparing the different diets.

\section{Discussion}

Better growth of the fish fed the reference diet compared with our experimental diets seems to have been caused mainly by the highly significant difference in feed intake. This suggests that the main difference was in organoleptic properties or in the technical quality of the feed, rather than in the nutrient composition. The commercial diet contained less residue, indicating less plant material of unrefined qualities than our diets, which could affect palatability. The close to significant better FCR in the same reference diet group is often seen as a consequence of improved growth ${ }^{(56)}$. Furthermore, higher energy and protein levels could have a positive effect on FCR. Using requirements for other fish species for Fe, Zn, $\mathrm{Mn}, \mathrm{Cu}$ and vitamin $\mathrm{B}_{6}$, our experimental diets were above these ${ }^{(57)}$, despite being lower than the commercial feed. The nutritional requirements of zebrafish are largely unknown ${ }^{(5)}$, and despite differences from the commercial diet, our experimental diets supported satisfactory growth for the purpose of the present experiment.

The higher weight in fish fed GM maize compared with non-GM was only revealed when the sex of the fish was taken into account. The highly significant sex differences resulted in large variations within diet groups and thus low statistical power when this variability was unaccounted for. Zebrafish females are larger and allocate energy into eggs rather than muscle as they go into maturation ${ }^{(58)}$. A possible explanation for the effect of maize variety could be by different levels of mycotoxins. Large variability in mycotoxin is observed between crops and years in both GM and non-GM maize, but the general trend is reduced levels in Bt maize 
Table 8. Transcription of mRNA

(Mean values with their standard errors of diet group)

\begin{tabular}{|c|c|c|c|c|c|c|c|c|c|c|c|}
\hline & \multicolumn{2}{|c|}{ non-GM } & \multicolumn{2}{|c|}{ mGM } & \multicolumn{2}{|c|}{ sGM } & \multicolumn{2}{|c|}{ smGM } & \multirow[b]{2}{*}{ Soya } & \multirow[b]{2}{*}{ Maize } & \multirow[b]{2}{*}{ Sex } \\
\hline & Mean & SEM & Mean & SEM & Mean & SEM & Mean & SEM & & & \\
\hline HSP7O & 8.31 & 4.34 & 1.24 & 0.61 & 7.53 & 4.82 & $1 \cdot 18$ & 0.40 & NS & NS $(P=0.08)$ & NS \\
\hline$H S P 90 \alpha$ & 3.70 & 1.56 & $2 \cdot 62$ & 1.37 & $1 \cdot 18$ & 0.45 & 3.70 & $2 \cdot 76$ & NS & NS & NS \\
\hline$D N A-r . p$ & 0.93 & 0.19 & 1.63 & 0.34 & $1 \cdot 17$ & 0.18 & $1 \cdot 27$ & 0.32 & NS & NS & NS \\
\hline$S O D-1$ & $1 \cdot 24$ & 0.19 & 1.13 & 0.15 & 1.26 & $0 \cdot 16$ & 0.94 & 0.22 & NS & $P=0.03$ & $P=0.03$ \\
\hline$G P x-1$ & 1.24 & 0.23 & 1.84 & 0.25 & 1.37 & 0.31 & 0.84 & 0.20 & NS & NS & NS \\
\hline
\end{tabular}

HSP, heat shock protein; DNA-r.p., DNA repair protein; SOD, superoxide dismutase; GPx, glutathione peroxidase; min, minimum; max, maximum.

The statistical testing was done on the $\log (2)$ of the normalised quantities, not with the individual diet groups, but with soya variety and maize variety as factors (GM $v$. non-GM). Three fish from each tank (nine from each diet group) were used. Sex and RNA integrity number value were included in the model if significant. SOD-1 had a GM soya-sex interaction effect, significant with a $p$ value of 0.004

compared with conventional maize varieties, due to better resistance against Fusarium spp. ${ }^{(59-62)}$. This has been used to explain higher weight gain in the GM-fed group in three studies with broilers, broiler chicks and piglets, respectively (reviewed by Flachowsky et al. ${ }^{(63)}$, although, in these studies, the hypothesis was supported by mycotoxin results that we do not have. In a study with Atlantic salmon fed the exact same batch of GM maize as in the present study, reduced growth was seen in the GM group, caused by a somewhat lower feed intake ${ }^{(9)}$

The effect on feed intake of soya variety (non-GM or GM) was not supported by changes in growth or feed conversion ratio, thus seems to be of little biological relevance. The difference is possibly due to the difficulty of making sure there was never excess feeding, making the feed intake estimates inaccurate.

The interaction effects between soya variety and sex on total liver RNA yield and SOD-1 expression indicate that there is a difference between the non-GM and GM soya that affects male and female fish differently. Soya isoflavones are phyto-oestrogens known to affect sex hormones and reproduction in mammals ${ }^{(64-67)}$, and have been shown to induce vitellogenesis in sturgeon but not in rainbow trout ${ }^{(68,69)}$. Isoflavones are products of the shikimate pathway, which is the target of the herbicide glyphosate. It has been hypothesised that isoflavone content may be reduced in glyphosate-tolerant soya ${ }^{(70)}$. However, differences have not been found when comparing glyphosate-treated to hand-weeded $\operatorname{RRS}^{\circledR(70)}$, nor when comparing $\operatorname{RRS}^{\circledR}$ to its non-modified maternal line ${ }^{(71-73)}$. Isoflavone levels were not measured in our diets, and thus it remains a speculation whether they are to blame for the observed effects. Significantly higher $S O D-1$ liver transcription in zebrafish fed non-GM maize is not supported by further results from the previously mentioned salmon study $^{(10)}$. In that study, SOD-1 transcription in liver was equal between the diet groups, but total SOD enzyme activity (includes both the soluble isoform, SOD-1 and SOD-2 in mitochondria) was higher in both the liver and distal intestine in the GM group. Higher expression in females than males is consistent with what has been observed in other animals such as rats and hamsters ${ }^{(74,75)}$. Furthermore, our increase (although not significant) in HSP70 in the non-GM maize groups differs from the salmon study ${ }^{(10)}$. In salmon, no differences were seen at the mRNA level, while the HSP70 protein was increased in the liver of fish fed the GM maize compared with a reference diet, while the non-GM maize diet exhibited intermediate levels. Maybe species differences can explain the opposite effects found in salmon and zebrafish, and further there was no maturation in the salmon study. Neither our difference in growth nor in $S O D-1$ would not have been revealed without taking sex into account.

Furthermore, it must be taken into account that the difference in SOD-1 transcription between the diet groups is minor (1.2-fold) and smaller than the difference between male and female fish. It is not known whether the difference by diet has any physiological relevance, although the corresponding effect on growth might suggest that it does. Given the effect on growth, other molecular markers including genes involved in metabolism might have given interesting results. However, limited sample material was available, and a focus on stress-related genes was chosen, because stress response had been singled out as a potential effect of GM feed $^{(10)}$ and to obtain comparative data with salmon to evaluate the utility of zebrafish as a model.

The results on the uptake of dietary DNA sequences support those studies referred to in the introduction, reporting that dietary DNA can withstand feed processing and be taken up by the fish intestine and be distributed to various tissues of the fish. There are similar reports of the same from various other animals ${ }^{(76-84)}$. This is, however, not specific to transgenic DNA, as the same happened with rubisco both in the

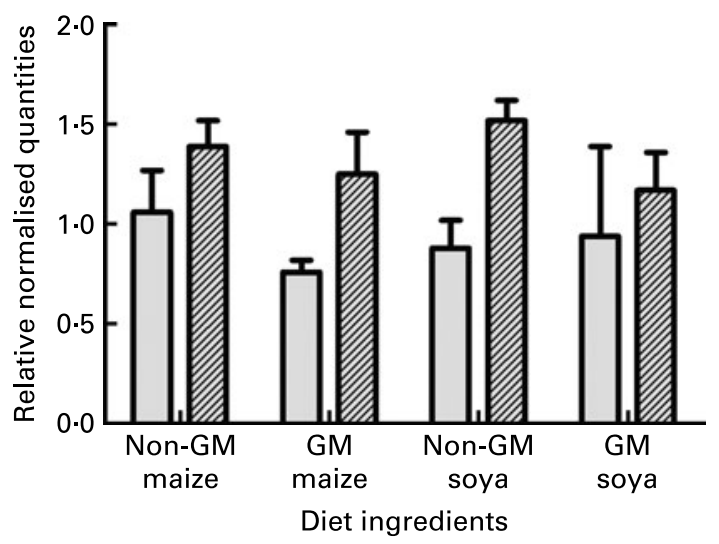

Fig. 2. Superoxide dismutase (SOD)-1 transcription in liver. The data are given as the means with their standard errors as the error bar ( $\square$, male; $\square$, female). Sex: $P=0.03$; maize variety: $P>0.03$; soya-sex interaction: $P=0.004$. 
present study and others ${ }^{(85)}$. Rubisco is present in plants cells in high copy numbers, which is likely the cause why this sequence was detected much more frequently than the transgenic DNA. The present results give no reason to suspect that transgenic sequences should be taken up more frequently than regular plant DNA. However, it is interesting to see that dietary DNA is detectable in all tissues analysed also in zebrafish.

The presence of MON810 DNA fragments in intestinal organs could be explained by residual feed in the intestine, and it cannot be ruled out that the presence of MON810 DNA fragments in one liver sample could be explained by

Table 9. DNA fragments from Roundup Ready ${ }^{\circledR}$ soya $\left(\mathrm{RRS}^{\circledR}\right)$, MON810 and rubisco detected the four diets (Mean values and standard deviations)

\begin{tabular}{|c|c|c|c|c|c|c|c|c|}
\hline \multirow[b]{2}{*}{ Diet } & \multicolumn{2}{|c|}{ RRS $®$} & \multicolumn{2}{|c|}{ MON810 } & \multicolumn{2}{|c|}{ sRubisco } & \multicolumn{2}{|c|}{ mRubisco } \\
\hline & $\mathrm{PFU}^{1} / \mu \mathrm{g}$ DNA & $\pm \min / \max$ & $\mathrm{PFU} / \mu \mathrm{g}$ DNA & $\pm \min / \max$ & 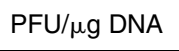 & SD & $\mathrm{PFU} / \mu \mathrm{g}$ DNA & SD \\
\hline non-GM & $12 \cdot 6$ & $8 \cdot 4$ & 3.8 & 0.7 & $2.64 \times 10^{7}$ & $4.43 \times 10^{6}$ & $4.49 \times 10^{6}$ & $2.51 \times 10^{5}$ \\
\hline mGM & 18.9 & 8.9 & 8809.4 & $432 \cdot 5$ & $3.73 \times 10^{7}$ & $9.44 \times 10^{6}$ & $6.68 \times 10^{6}$ & $8.47 \times 10^{4}$ \\
\hline sGM & $7.16 \times 10^{4}$ & $7783 \cdot 1$ & 38.5 & $7 \cdot 1$ & $6.69 \times 10^{7}$ & $2.01 \times 10^{6}$ & $8.64 \times 10^{6}$ & $8.58 \times 10^{5}$ \\
\hline smGM & $7.33 \times 10^{4}$ & $7176 \cdot 8$ & $1.29 \times 10^{4}$ & $587 \cdot 5$ & $9.05 \times 10^{7}$ & $1.77 \times 10^{7}$ & $1.13 \times 10^{7}$ & $1.37 \times 10^{6}$ \\
\hline
\end{tabular}

sRubisco, rubisco gene from soya; mRubisco, rubisco gene from maize; PFU, PCR-forming unit

Rubisco was quantified by qPCR using a standard curve (two parallels and two dilutions of DNA). RRS ${ }^{\circledR}$ and MON810 were quantified by qPCR using a standard curve (one parallel and two dilutions of DNA).

Table 10. MON810 detected in organs of zebrafish using SIMQUANT (eight parallels)

\begin{tabular}{|c|c|c|c|c|c|c|c|c|c|}
\hline \multirow[b]{2}{*}{ Diet } & \multirow[b]{2}{*}{ Tank } & \multicolumn{2}{|c|}{ Brain } & \multicolumn{2}{|c|}{ Muscle } & \multicolumn{2}{|c|}{ Liver } & \multicolumn{2}{|c|}{ Intestinal organs } \\
\hline & & $\mathrm{PFU} / \mu \mathrm{g}$ DNA & $95 \% \mathrm{Cl}$ & $\mathrm{PFU} / \mu \mathrm{g}$ DNA & $95 \% \mathrm{Cl}$ & $\mathrm{PFU} / \mu \mathrm{g}$ DNA & $95 \% \mathrm{Cl}$ & $\mathrm{PFU} / \mu \mathrm{g}$ DNA & $95 \% \mathrm{Cl}$ \\
\hline non-GM & 3 & $-{ }^{*}$ & & ND & & ND & & ND & \\
\hline non-GM & 8 & ND & & ND & & ND & & ND & \\
\hline non-GM & 11 & ND & & ND & & ND & & ND & \\
\hline mGM & 12 & ND & & ND & & ND & & 0.36 & $0.03,0.73$ \\
\hline mGM & 13 & ND & & ND & & 0.32 & $0.02,0.64$ & 3.89 & $2.56,6.56$ \\
\hline mGM & 15 & ND & & ND & & ND & & ND & \\
\hline sGM & 1 & ND & & ND & & ND & & ND & \\
\hline sGM & 4 & ND & & ND & & ND & & ND & \\
\hline sGM & 7 & ND & & ND & & ND & & ND & \\
\hline smGM & 2 & ND & & ND & & ND & & 0,15 & $0.01,0.30$ \\
\hline smGM & 6 & ND & & ND & & ND & & ND & \\
\hline smGM & 10 & ND & & ND & & ND & & 0,25 & $0.02,0.51$ \\
\hline
\end{tabular}

PFU, PCR-forming unit; ND, not detected.

*No sample available.

Table 11. Soya rubisco detected in organs of zebrafish using a standard curve (two parallels)

\begin{tabular}{|c|c|c|c|c|c|c|c|c|c|}
\hline \multirow[b]{2}{*}{ Diet } & \multirow[b]{2}{*}{ Tank } & \multicolumn{2}{|c|}{ Brain } & \multicolumn{2}{|c|}{ Muscle } & \multicolumn{2}{|c|}{ Liver } & \multicolumn{2}{|c|}{ Intestinal organs } \\
\hline & & $\mathrm{PFU} / \mu \mathrm{g}$ DNA & $\pm \min / \max$ & $\mathrm{PFU} / \mu \mathrm{g}$ DNA & $\pm \min / \max$ & $\mathrm{PFU} / \mu \mathrm{g}$ DNA & $\pm \min / \max$ & $\mathrm{PFU} / \mu \mathrm{g}$ DNA & $\pm \min / \max$ \\
\hline non-GM & 3 & $-{ }^{*}$ & & $11 \cdot 7$ & & $50 \cdot 6$ & $1 \cdot 4$ & $7580 \cdot 0$ & $847 \cdot 0$ \\
\hline non-GM & 8 & $62 \cdot 8$ & $11 \cdot 8$ & $148 \cdot 0$ & 91.4 & ND & & $5560 \cdot 0$ & $1210 \cdot 0$ \\
\hline non-GM & 11 & $116 \cdot 0$ & $98 \cdot 8$ & $117 \cdot 0$ & $16 \cdot 0$ & $27 \cdot 0$ & 1.9 & $1.14 \times 10^{4}$ & $940 \cdot 0$ \\
\hline mGM & 12 & ND & & $46 \cdot 7$ & $35 \cdot 4$ & $55 \cdot 4$ & $25 \cdot 6$ & $2490 \cdot 0$ & $412 \cdot 0$ \\
\hline mGM & 13 & $37 \cdot 9$ & & $420 \cdot 0$ & $12 \cdot 3$ & $124 \cdot 0$ & $21 \cdot 5$ & $3.28 \times 10^{4}$ & $3670 \cdot 0$ \\
\hline mGM & 15 & $20 \cdot 0$ & & ND & & $8 \cdot 7$ & 1.6 & $7130 \cdot 0$ & $1430 \cdot 0$ \\
\hline sGM & 1 & $29 \cdot 6$ & $2 \cdot 8$ & $296 \cdot 0$ & $21 \cdot 6$ & ND & & $1120 \cdot 0$ & $56 \cdot 0$ \\
\hline sGM & 4 & ND & & 115.0 & & $3.9 \times 10^{4}$ & $4820 \cdot 0$ & $2370 \cdot 0$ & $188 \cdot 0$ \\
\hline sGM & 7 & ND & & $88 \cdot 3$ & $32 \cdot 8$ & 593.0 & 74.7 & $9.11 \times 10^{4}$ & $5370 \cdot 0$ \\
\hline smGM & 2 & $258 \cdot 0$ & $95 \cdot 3$ & ND & & $19 \cdot 0$ & 4.0 & $1.05 \times 10^{4}$ & $202 \cdot 0$ \\
\hline smGM & 6 & $15 \cdot 3$ & & ND & & $4 \cdot 2$ & & $2170 \cdot 0$ & $49 \cdot 2$ \\
\hline smGM & 10 & $77 \cdot 1$ & $19 \cdot 8$ & $27 \cdot 2$ & & ND & & $2.81 \times 10^{4}$ & $2540 \cdot 0$ \\
\hline
\end{tabular}

PFU, PCR-forming unit; ND, not detected.

In wells without $\mathrm{min} / \mathrm{max}$ values, soya rubisco could only be detected in one out of the two parallels. When only one parallel was positive, the PFU of that parallel is presented

in the table.

* No sample available. 
Table 12. Maize rubisco detected in organs of zebrafish using a standard curve (two parallels)

\begin{tabular}{|c|c|c|c|c|c|c|c|c|c|}
\hline \multirow[b]{2}{*}{ Diet } & \multirow[b]{2}{*}{ Tank } & \multicolumn{2}{|c|}{ Brain } & \multicolumn{2}{|c|}{ Muscle } & \multicolumn{2}{|c|}{ Liver } & \multicolumn{2}{|c|}{ Intestinal organs } \\
\hline & & PFU/mg DNA & $\pm \min / \max$ & $\mathrm{PFU} / \mathrm{mg}$ DNA & $\pm \min / \max$ & $\mathrm{PFU} / \mathrm{mg} \mathrm{DNA}$ & $\pm \min / \max$ & $\mathrm{PFU} / \mathrm{mg} \mathrm{DNA}$ & $\pm \min / \max$ \\
\hline non-GM & 3 & $-{ }^{\star}$ & & 4.7 & $4 \cdot 3$ & ND & & $50 \cdot 4$ & 7.5 \\
\hline non-GM & 8 & $5 \cdot 3$ & 4.2 & ND & & ND & & $180 \cdot 0$ & 4.6 \\
\hline non-GM & 11 & ND & & ND & & $2 \cdot 3$ & & 224.0 & 11.7 \\
\hline $\mathrm{mGM}$ & 12 & ND & & ND & & $2 \cdot 2$ & & $412 \cdot 0$ & $47 \cdot 2$ \\
\hline mGM & 13 & $27 \cdot 2$ & & $106 \cdot 0$ & $77 \cdot 4$ & $675 \cdot 0$ & $53 \cdot 8$ & $1.34 \times 10^{4}$ & $148 \cdot 0$ \\
\hline mGM & 15 & ND & & ND & & ND & & $31 \cdot 3$ & 0.17 \\
\hline sGM & 1 & $8 \cdot 1$ & & $4 \cdot 1$ & 1.2 & ND & & 33.0 & 3.4 \\
\hline sGM & 4 & ND & & ND & & 22.9 & 8.6 & $52 \cdot 1$ & $2 \cdot 3$ \\
\hline sGM & 7 & ND & & 8.1 & & $16 \cdot 2$ & $4 \cdot 1$ & $577 \cdot 0$ & $20 \cdot 4$ \\
\hline smGM & 2 & ND & & 0.04 & & 1.1 & 0.85 & $122 \cdot 0$ & 3.7 \\
\hline smGM & 6 & ND & & $8 \cdot 2$ & 0.57 & 0.4 & & $140 \cdot 0$ & $13 \cdot 1$ \\
\hline smGM & 10 & 37.6 & & $26 \cdot 1$ & & ND & & $367 \cdot 0$ & $9 \cdot 3$ \\
\hline
\end{tabular}

PFU, PCR-forming unit; ND, not detected.

In wells w/o min/max values, mRubisco could only be detected in one out of two parallels. When only one parallel was positive, the PFU of that parallel is presented in the table.

${ }^{*}$ No sample available.

contamination from the intestinal organs during sampling. The fact that we were not able to detect transgenic DNA in any of the other organs could be due to limitations in sensitivity, and the presence of these DNA fragments in the organs can therefore not be ruled out. No difference in the uptake of rubisco between the diet groups shows that the transgenic DNA does not modify the uptake of other dietary DNA fragments. This is in agreement with Mazza et al. ${ }^{(82)}$ who found no difference in the uptake of specific maize genes when comparing piglets fed non-GM or MON810 maize. Similar findings have also been done by others ${ }^{(80,83)}$. Contrary to a higher level of the RRS $^{\circledR}$ than the MON810 fragments detected in the diets, only MON810 and not RRS ${ }^{\circledR}$ could be detected in the intestinal organs. There are two possible explanations to this. Either there is some sequence specificity in the DNA uptake, which would also indicate that the detected DNA fragments in intestinal organs have been taken up by the fish and not from residual feed. Alternatively, there might be differences in the stability of different DNA fragments in the intestine, dependent on DNA sequence, methylation patterns or similar. The feed matrix can also influence the persistence and stability of DNA in the intestine ${ }^{(86,87)}$.

\section{Conclusions}

Differences were apparent between zebrafish fed non-GM and GM maize in the present study. The fish fed GM maize showed better growth and lower transcription levels of $S O D-1$ and possibly also $H S P 70$, which could indicate a stress response in the fish fed non-GM maize. All these effects were inconsistent with an earlier salmon trial.

Interaction effects between soya variety and sex were found in RNA yield from liver and SOD-1 transcription, both parameters with marked sex differences. This suggests that some diet component that affects males and females differently was present in different levels in the GM and the nonGM soya used in the present study.

Dietary DNA sequences were detected in low levels in fish tissues. The multicopy gene rubisco was detected much more frequently than the transgene fragments, and the $\mathrm{RRS}^{\circledR}$ sequence was not detected at all despite being higher than
MON810 in the diets, suggesting that there was not a linear relationship between amount present in feed and the amount of detected in the fish.

The present study also provides support for the feasibility of using zebrafish as a model organism, not only in relation to chemical toxicology, but also to study the safety of whole foods. Dietary DNA seemed to behave similarly to what has been reported from other species, while the different responses to GM maize compared with salmon are hard to explain.

\section{Acknowledgements}

We would like to thank The Monsanto Company for kindly supplying the $\mathrm{RRS}^{\circledR}$ and MON810 as well as the near-isogenic maternal soyabeans and maize. No financial support was given by Monsanto; the present work was supported in full by the Norwegian Research Council, Grant No. 172151. Thanks to Elin Kronstad for technical assistance in the zebrafish laboratory. Contributions of the authors. A. N. and N. H. S. were responsible for diet formulation and production; N. H. S., E. M. H., A. N. and G-.I. H. participated in the practical work of the feeding trial and sampling; N. H. S. did the mRNA transcription analysis, feed data, statistical analysis and was the main author of the manuscript; L. E. J., C. R. W-.N. and K. G. B. conducted the tracing of dietary DNA and authored the parts of the manuscript regarding this. All authors have contributed to the writing and revision of the final manuscript. Conflict of interest. The Monsanto Company provided the GM ingredients and the near-isogenic maternal lines. However, no financial support was received from Monsanto, as the project was supported in full by the Norwegian Research Council.

\section{References}

1. Driever W, Stemple D, Schier A, et al. (1994) Zebrafish: genetic tools for studying vertebrate development. Trends Genet 10, 152-159.

2. Fishman MC (2001) Genomics. Zebrafish - the canonical vertebrate. Science 294, 1290-1291.

3. Penberthy WT, Shafizadeh E \& Lin S (2002) The zebrafish as a model for human disease. Front Biosci 7, 1439-1453. 
4. Hill AJ, Teraoka H, Heideman W, et al. (2005) Zebrafish as a Model Vertebrate for Investigating Chemical Toxicity. Toxicol Sci 86, 6-19.

5. Lawrence C (2007) The husbandry of zebrafish (Danio rerio): a review. Aquaculture 269, 1-20.

6. Sanden M (2004) Genetically Modified Plant Products in Feed to Farmed Atlantic Salmon, Salmo salar L. - Effects on Growth, Feed Utilization, Fish Health and Assessment of Potential Risks. Bergen: Department of Fisheries and Marine Biology, University of Bergen.

7. Buddington RK, Krogdahl A \& Bakke-McKellep AM (1997) The intestines of carnivorous fish: structure and functions and the relations with diet. Acta Physiol Scand Suppl 638, 67-80.

8. Kaushik SJ \& Hemre G-I (2008) Plant proteins as alternative sources for fish feed and farmed fish quality. In Improving Farmed Fish Quality and Safety, pp. 300-319, chapter 12 [Ø Lie, editor]. Cambridge: Woodhead Publishing Limited/ CRC Press.

9. Hemre GI, Sagstad A, Bakke-Mckellep AM, et al. (2007) Nutritional, physiological, and histological responses in Atlantic salmon, Salmo salar L. fed diets with genetically modified maize. Aqua Nutr 13, 186-199.

10. Sagstad A, Sanden M, Haugland $\varnothing$, et al. (2007) Evaluation of stress- and immune-response biomarkers in Atlantic salmon, Salmo salar L., fed different levels of genetically modified maize (Bt maize), compared with its near-isogenic parental line and a commercial suprex maize. J Fish Dis 30, 201-212.

11. Sanden M, Krogdahl A, Bakke-Mckellep AM, et al. (2006) Growth performance and organ development in Atlantic salmon, Salmo salar L. parr fed genetically modified (GM) soybean and maize. Aqua Nutr 12, 1-14.

12. Hammond BG, Vicini JL, Hartnell GF, et al. (1996) The feeding value of soybeans fed to rats, chickens, catfish and dairy cattle is not altered by genetic incorporation of glysophate tolerance. J Nutr 126, 717-727.

13. Hemre GI, Sanden M, Bakke-Mckellep AM, et al. (2005) Growth, feed utilization and health of Atlantic salmon Salmo salar L. fed genetically modified compared to non-modified commercial hybrid soybeans. Aqua Nutr 11, 157-167.

14. Sagstad A, Sanden M, Krogdahl A, et al. (2008) Organs development, gene expression and health of Atlantic salmon (Salmo salar L.) fed genetically modified soybeans compared to the nearisogenic non-modified parental line. Aqua Nutr 14, 556-572.

15. Chainark P, Satoh S, Hino T, et al. (2006) Avalability of genetically modified soybean meal in rainbow trout Oncorhynchus mykiss diets. Fisheries Sci 72, 1072-1078.

16. Sissener NH, Sanden M, Bakke AM, et al. (2009) A long term trial with Atlantic salmon (Salmo salar L.) fed genetically modified soy; focusing general health and performance before, during and after the parr-smolt transformation. Aquaculture 241, 108-117.

17. Bakke-McKellep AM, Sanden M, Danieli A, et al. (2008) Atlantic salmon (Salmo salar L.) parr fed genetically modified soybeans and maize: histological, digestive, metabolic, and immunological investigations. Res Vet Sci 84, 395-408.

18. Sanden M, Berntssen MHG, Krogdahl A, et al. (2005) An examination of the intestinal tract of Atlantic salmon, Salmo salar L., parr fed different varieties of soy and maize. J Fish Dis 28, 317-330.

19. Jonas DA, Elmadfa I, Engel KH, et al. (2001) Safety considerations of DNA in food. Ann Nutr Metab 45, 235-254

20. Alexander TW, Reuter T, Aulrich K, et al. (2007) A review of the detection and fate of novel plant molecules derived from biotechnology in livestock production. Anim Feed Sci Technol 133, 31-62.

21. Sanden M, Bruce IJ, Rahman MA, et al. (2004) The fate of transgenic sequences present in genetically modified plant products in fish feed, investigating the survival of GM soybean
DNA fragments during feeding trials in Atlantic salmon, Salmo salar L. Aquaculture 237, 391-405.

22. Nielsen CR, Berdal KG, Bakke-McKellep AM, et al. (2005) Dietary DNA in blood and organs of Atlantic salmon (Salmo salar L.). Eur Food Res Technol 221, 1-8.

23. Nielsen C, Holst-Jensen A, Løvseth A, et al. (2006) Persistence and distribution of intravenously injected DNA in blood and organs of Atlantic salmon (Salmo salar L.). Eur Food Res Technol 222, 258-265.

24. Chainark P, Satoh S, Hirono I, et al. (2008) Availability of genetically modified feed ingredient: investigations of ingested foreign DNA in rainbow trout Oncorhynchus mykiss. Fisheries Sci 74, 380-390.

25. Sanden M, Berntssen M \& Hemre G-I (2007) Intracellular localization of dietary and naked DNA in intestinal tissue of Atlantic salmon, Salmo salar L. using in situ hybridization. Eur Food Res Technol 225, 533-543.

26. EFSA (2006) Guidance document of the Scientific Panel on Genetically Modified Organisms for the risk assessment of genetically modified plants and derived food and feed. (EFSA ed.) ESFA $J 1-100$

27. ILSI (2003) Best Practices for the Conduct of Animal Studies to evaluate Crops Genetically Modified for Output traits. Washington, DC: International Food Biotechnology Committee, International Life Sceinces Institute. http://wwwilsiorg/NR/ rdonlyres/4A2F7C13-B4AA-4BC9-AEDE-696B4B72E3C4/0/ BestPracticesGuidelinespdf

28. Cowieson AJ (2005) Factors that affect the nutritional value of maize for broilers. Anim Feed Sci Technol 119, 293-305.

29. Lie $\varnothing ~(1991)$ Studies of digestion, deposition and fatty acid composition of lipids in cod (Gadus morhua). $\mathrm{PhD}$ thesis, University of Bergen, Bergen.

30. AOAC (1995) AOAC Official Methods of Analysis Method 992.15: Crude Protein in Meat and Meat Products, Combustion Method, 16th ed. Arlington, VA: AOAC.

31. Hemre GI, Lie Ø, Lied E, et al. (1989) Starch as an energy source in feed for cod (Gadus morhua) -digestibility and retention. Aquaculture 80, 261-270.

32. CEN (2002) Foodstuffs - Determination of vitamin B6 (including its glycosylated forms) by HPLC. ENV14164 Comite Europe'en de Normalisation (CEN) TC275 WI 00275131.

33. Julshamn K, Brenna J, Holland R, et al. (1999) Plasma source mass spectrometry - new developments and applications. $R$ Soc Chem 241, 167-172.

34. Dmitrovic J, Chan SC \& Chan SHY (2002) Analysis of pesticides and PCB congeners in serum by GC/MS with SPE sample cleanup. Toxicol Lett 134, 253-258.

35. Barranco A, Alonso-Salces RM, Bakkali A, et al. (2003) Solidphase clean-up in the liquid chromatographic determination of polycyclic aromatic hydrocarbons in edible oils. J Chromatogr A 988, 33-40.

36. Murtha JM \& Keller ET (2003) Characterization of the heat shock response in mature zebrafish (Danio rerio). Exp Gerontol 38, 683-691.

37. Olsvik P, Lie K, Stavrum A-K, et al. (2007) Gene-expression profiling in gill and liver of zebrafish exposed to produced water. Int J Environ Anal Chem 87, 195-210.

38. Malek RL, Sajadi H, Abraham J, et al. (2004) The effects of temperature reduction on gene expression and oxidative stress in skeletal muscle from adult zebrafish. Comp Biochem Physiol C Toxicol Pharmacol 138, 363-373.

39. Tang R, Dodd A, Lai D, et al. (2007) Validation of zebrafish (Danio rerio) reference genes for quantitative real-time RTPCR normalization. Acta Biochim Biophys Sin 39, 384-390.

40. Higuchi R, Fockler C, Dollinger G, et al. (1993) Kinetic PCR analysis: real-time monitoring of DNA amplification reactions. Nat Biotech 11, 1026-1030. 
41. Vandesompele J, De Preter K, Pattyn F, et al. (2002) Accurate normalization of real-time quantitative RT-PCR data by geometric averaging of multiple internal control genes. Genome Biol 3, research0034.1-research0034.11.

42. Andersen CL, Jensen JL \& Orntoft TF (2004) Normalization of real-time quantitative reverse transcription-PCR data: a modelbased variance estimation approach to identify genes suited for normalization. Applied to bladder and colon cancer data sets. Cancer Res 64, 5245-5250.

43. GMO-CRL (2006) http://gmo-crl.jrc.it/detectionmethods/NK603WEB-Protocol\%20Validation.pdf

44. Berdal KG \& Holst-Jensen A (2001) Roundup Ready ${ }^{\circledR}$ soybean event-specific real-time quantitative PCR assay and estimation of the practical detection and quantification limits in GMO analyses. Eur Food Res Technol 213, 432-438.

45. GMO-CRL (2006) http://gmo-crl.jrc.ec.europa.eu/summaries/ Mon810_validation_report.pdf

46. Chandler DP (1998) Redefining relativity: quantitative PCR at low template concentrations for industrial and environmental microbiology. J Ind Microbiol Biotechnol 21, 128-140.

47. Berdal KG, Bøydler C, Tengs T, et al. (2008) A statistical approach for evaluation of PCR results to improve the practical limit of quantification (LOQ) of GMO analyses (SIMQUANT). Eur Food Res Technol 227, 1149-1157.

48. NMKL (2002) Measurement of uncertainty in microbiological examination in foods, NMKL-procedure No 8.

49. Ruohonen K (1998) Individual measurements and nested designs in aquaculture experiments: a simulation study. Aquaculture 165, 149-157.

50. Ling EN \& Cotter D (2003) Statistical power in comparative aquaculture studies. Aquaculture 224, 159-168.

51. Zar JH (1999) Biostatistical Analysis, 4th ed. Englewood Cliffs, NJ: Prentice Hall.

52. Bustin SA \& Nolan T (2004) Pitfalls of quantitative real-time reverse-transcription polymerase chain reaction. J Biomol Technol 15, 155-166.

53. Imbeaud S, Graudens E, Boulanger V, et al. (2005) Towards standardization of RNA quality assessment using user-independent classifiers of microcapillary electrophoresis traces. Nucleic Acids Res 33, e56.

54. Fleige S, Walf V, Huch S, et al. (2006) Comparison of relative mRNA quantification models and the impact of RNA integrity in quantitative real-time RT-PCR. Biotechnol Lett 28, 1601-1613.

55. De Luis R, Pérez MD, Sánchez L, et al. (2008) Kinetic and thermodynamic parameters for heat denaturation of Cry1A(b) protein from transgenic maize (Zea mays). J Food Sci 73, C447-C451.

56. Nordgarden U, Oppedal F, Taranger GL, et al. (2003) Seasonally changing metabolism in Atlantic salmon (Salmo salar L.); growth and feed conversion ratio. Aqua Nutr 9, 287-293.

57. NRC (1993) Nutrient Requirement of Fish. Washington, DC National Research Council, National academy press.

58. Hevrøy EM, Tonheim S, Rønnestad I, et al. (2007) Zebrafish as a genetic model for the nutritional impact on growth in fish. The Norwegian Biochemical Society 43 Contact Meeting February 1-4, Lillehammer, Norway.

59. Bakan B, Melcion D, Richard-Molard D, et al. (2002) Fungal growth and fusarium mycotoxin content in isogenic traditional maize and genetically modified maize grown in France and Spain. J Agric Food Chem 50, 728-731.

60. Dowd PF (2000) Indirect reduction of ear molds and associated mycotoxins in Bacillus thuringiensis corn under controlled and open fields conditions: Utility and limitations. J Econ Entomol 1669-1679.

61. Papst C, Utz HF, Melchinger AE, et al. (2005) Mycotoxins produced by Fusarium spp. in isogenic Bt vs. non-Bt maize hybrids under European corn borer pressure. Agron J 97, 219-224.
62. Munkvold GP, Hellmich RL \& Showers WB (1997) Reduced Fusarium Ear Rot and symptomless infection in kernels of maize genetically engineered for European corn borer resistance. Phytopathology 87, 1071-1077.

63. Flachowsky G, Chesson A \& Aulrich K (2005) Animal nutrition with feeds from genetically modified plants. Arch Anim Nutr 1, $1-40$.

64. Adlercreutz H, Höckerstedt K, Bannwart C, et al. (1987) Effect of dietary components, including lignans and phytoestrogens, on enterohepatic circulation and liver metabolism of estrogens and on sex hormone binding globulin (SHBG). J Steroid Biochem Mol Biol 27, 1135-1144.

65. Duncan AM, Merz BE, Xu X, et al. (1999) Soy isoflavones exert modest hormonal effects in premenopausal women. J Clin Endocrinol Metab 84, 192-197.

66. Bennetts HW, Uuderwood EJ \& Shier FL (1946) A specific breeding problem of sheep on subterranen clover pastures in Western Australia. Aust Vet J 22, 2-12.

67. Setchell KD, Gosselin SJ, Welsh MB, et al. (1987) Dietary estrogens - a probable cause of infertility and liver disease in captive cheetahs. Gastroenterology 93, 225-233.

68. Pelissero C, Bennetau B, Babin P, et al. (1991) The estrogenic activity of certain phytoestrogens in the Siberian sturgeon Acipenser baeri. J Steroid Biochem Mol Biol 38, 293-299.

69. Latonnelle K, Le Menn F, Kaushik SJ, et al. (2002) Effects of dietary phytoestrogens in vivo and in vitro in rainbow trout and Siberian sturgeon: interests and limits of the in vitro studies of interspecies differences. Gen Comp Endocrinol 126, 39-51.

70. Duke SO, Rimando AM, Pace PF, et al. (2003) Isoflavone, glyphosate, and aminomethylphosphonic acid levels in seeds of glyphosate-treated, glyphosate-resistant soybean. J Agric Food Chem 51, 340-344.

71. Padgette SR, Taylor NB, Nida DL, et al. (1996) The composition of glyphosate-tolerant soybean seeds is equivalent to that of conventional soybeans. J Nutr 126, 702-716.

72. Taylor NB, Fuchs RL, MacDonald J, et al. (1999) Compositional analysis of glyphosate-tolerant soybeans treated with glyphosate. J Agric Food Chem 47, 4469-4473.

73. McCann MC, Liu K, Trujillo WA, et al. (2005) Glyphosatetolerant soybeans remain compositionally equivalent to conventional soybeans (Glycine $\max$ L.) during three years of field testing. J Agric Food Chem 53, 5331-5335.

74. Borrás C, Sastre J, García-Sala D, et al. (2003) Mitochondria from females exhibit higher antioxidant gene expression and lower oxidative damage than males. Free Radic Biol Med 34, $546-552$.

75. Coto-Montes A, Boga JA, Tomás-Zapico C, et al. (2001) Physiological oxidative stress model: Syrian hamster Harderian gland-sex differences in antioxidant enzymes. Free Radic Biol Med 30, 785-792.

76. Schubbert R, Renz D, Schmitz B, et al. (1997) Foreign (M13) DNA ingested by mice reaches peripheral leukocytes, spleen, and liver via the intestinal wall mucosa and can be covalently linked to mouse DNA. Proc Natl Acad Sci U S A 94, 961-966.

77. Schubbert R, Hohlweg U, Renz D, et al. (1998) On the fate of orally ingested foreign DNA in mice: chromosomal association and placental transmission to the fetus. Mol Gen Genet 259, 569-576.

78. Doerfler W \& Schubbert R (1998) How dangerous is genetically engineered food. Wien Klin Wochenschr 110, 411.

79. Einspanier R, Klotz A, Kraft J, et al. (2001) The fate of forage plant DNA in farm animals: a collaborative case-study investigating cattle and chicken fed recombinant plant material. Eur Food Res Techn 212, 129-134.

80. Reuter $\mathrm{T} \&$ \& Aulrich K (2003) Investigations on genetically modified maize (Bt-maize) in pig nutrition: fate of feed-ingested foreign DNA in pig bodies. Eur Food Res Techn 216, 185-192. 
81. Tony MA, Butschke A, Broll H, et al. (2003) Safety assessment of Bt 176 maize in broiler nutrition: degradation of maize DNA and its metabolic fate. Arch Anim Nutr 57, 235-252.

82. Mazza R, Soave M, Morlacchini M, et al. (2005) Assessing the transfer of genetically modified DNA from feed to animal tissues. Transgenic Res 14, 775-784.

83. Rossi F, Morlacchini M, Fusconi G, et al. (2005) Effect of $\mathrm{Bt}$ corn on broiler growth performance and fate of feed-derived DNA in the digestive tract. Poult Sci 84, $1022-1030$.

84. Sharma R, Damgaard D, Alexander TW, et al. (2006) Detection of transgenic and endogenous plant DNA in digesta and tissues of sheep and pigs fed roundup ready canola meal. J Agric Food Chem 54, 1699-1709.
85. Phipps RH, Deaville ER \& Maddison BC (2003) Detection of transgenic and endogenous plant DNA in rumen fluid, duodenal digesta, milk, blood, and feces of lactating dairy cows. J Dairy Sci 86, 4070-4078.

86. Straub JA, Hertel C \& Hammes WP (1999) The fate of recombinant DNA in thermally treated fermented sausages. Eur Food Res Technol 210, 62-67.

87. Palka-Santini M, Schwarz-Herzke B, Hösel M, et al. (2003) The gastrointestinal tract as the portal of entry for foreign macromolecules: fate of DNA and proteins. Mol Genet Genomics 270, 201-215.

88. Tacon AGJ (1987) The Nutrition and Feeding of Farmed Fish and Shrimp- A Training Manual:1. The essential nutrients. Brazil: Food and Agriculture Organization of the United Nations, pp. 117. GPC/RLA/075/ITA. 